\title{
ハイビジョン番組に適した字幕呈示パラメータの検討 〜最適な文字サイズと文字数〜
}

Presentation of Captions Suitable for Hi-Vision Programs -Optimum Size and Number-

\author{
工藤友彦 ${ }^{\dagger}$, 正会員 成田長人†
}

Tomohiko Kudo ${ }^{\dagger}$ and Nagato Narita ${ }^{\dagger}$

\begin{abstract}
Many TV programs broadcast captions for hearing-impaired people. Digital terrestrial television started in December 2003, so more Hi-Vision programs will be broadcast. Recently, since captions for Hi-Vision programs are produced using those for NTSC programs, the captions for Hi-Vision programs have been displayed in the same way as those of NTSC programs without modification. However, there are some differences between the viewing conditions for Hi-Vision and NTSC programs such as the screen aspect ratio and the preferable viewing distance. The presentation method of captions suitable for Hi-Vision needs to be investigated. We researched the letter size of captions and number of letters per line using a subjective evaluation test.
\end{abstract}

キーワード: 字幕呈示方法, ハイビジョン番組, 文字の大きさ, 文字数, 主観評価

\section{1.まえがき}

2003年12月に地上デジタル放送が始まり，ハイビジョン 規格による番組制作は増加している. 一方, 総務省では 1997年に，できる限り多くの番組で字幕を放送し，2007年 までには字幕付与可能なすべての番組で字幕放送するよう 放送法を改正した。

字幕呈示方法の研究はこれまで主にNTSC放送規格につい て行われてきた1)2).また，ハイビジョン放送の字幕呈示方 法は，現在，NTSC方式による放送番組（以下，NTSC放送） の字幕データをそのまま使用するなど, 字幕呈示方法は NTSC放送と同様になっている. 現行放送と一体化制作の八 イビジョン番組では, 現行放送を基準とし, 映像の両端に字 幕が入らないように制作していることが主な理由である.

地上デジタル放送の開始でハイビジョン放送が主流にな り，2007年を字幕放送可能な番組への字幕付与率100\%を 目標とする中，より見やすい字幕放送の実現のため, NTSC放送と画角の異なるハイビジョン放送の字幕呈示方 法の検討が求められる. ハイビジョン放送では, ディジ夕 ル技術の発達により受信機側での字幕呈示方法選択が可能 になることが考えられ，ハイビジョン放送における字幕呈 示のパラメー夕を調査しておく必要がある. 本論文では, ハイビジョン放送に適した字幕呈示法を, 主観評価を通し て検討する。

2004年11月19日受付，2005年7月11日最終受付，2005年8月 12 日採録

$†$ NHK放送技術局

( ⿳亠丷厂巾 150-8001 渋谷区神南2-2-1, TEL 03-5455-4913)

$\dagger$ NHK Broadcast Engineering Department

(2-2-1, Jinnan, Shibuya-ku, Tokyo, 150-8001, Japan

\section{2．評価用字幕の呈示パラメータの検討}

\section{1 ハイビジョン字幕の現状}

NTSC放送のニュース字幕の呈示に関して，主観評価に より, 字幕行数, 文字サイズ, 字幕表示領域, 字幕転換方 法 (総入れ替え, 横スクロール, 縦スクロール) の検討が行 われている1)2).

NTSC用字幕は, テレビ画面の重要情報範囲 (字幕が見切 れないセーフティーゾーン ; 画像の幅の $88 \%$, 高さの $89 \%$ ) 内で横15.5文字, 縦8.5行に分割された範囲に文字が表示さ れる.1文字の標準の大きさは横1文字・縦1行分で，半角 文字はその $1 / 2$ のきさ，ルビ表示の場合は $1 / 4$ 大大きさの 範囲を使用する。

現行ハイビジョンの字幕では，上記NTSCの表示形式を， サイドカットした部分の重要情報範囲内（画像の幅の $66 \%$, 高さの $89 \%$ )にのせて使用している.

\subsection{NTSCとハイビジョンの観視画角の違いの影響}

$4: 3$ のアスペクト比の画面を標準観視距離 $6 \mathrm{H}$ ( $\mathrm{H}$ ：画面 高) ${ }^{3)}$ から観視した場合, 画面を見込む画角は水平 $12.68^{\circ} \times$ 垂直 $9.53^{\circ}$ である。一方，16：99アスペクト比の画面を標 準観視距離 $3 \mathrm{H}^{4)}$ から観視した場合，画面を見达む画角は水 平 $33.01^{\circ} \times$ 垂直 $18.92^{\circ}$ である.

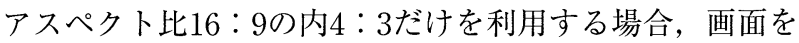
標準観視距離 $3 \mathrm{H}$ から観視すると，画面を見込む画角は水平 $25.06^{\circ} \times$ 垂直 $18.92^{\circ}$ となるため， $6 \mathrm{H}$ から観視した場合と比 べて観視者から見た文字サイズは相対的に大きくなる．逆 に，1文字を見达む視野角を現行方式と同じとすると，八 イビジョンでは水平約40文字/行を呈示できる.

(109) 1669 
以上より，本実験では，ハイビジョン放送に適した字幕 呈示方法の検討という位置付けから, 特にNTSCとHDTV の違いによる影響が顕著である，1行当たりの文字の大き さおよび文字数を変動パラメータとして主観評価実験を行 うこととした。

\section{3 予備実験}

呈示パラメータを変動させるレンジを決定するために, 評定者10名で予備実験を行った。 “ドラマ”番組に関して, 1行 (16：9の枠内) 当たり20文字，25文字，30文字が表示で きる3 種類の文字サイズで字幕を多重し，3Hの観視距離で 「全体の見やすさ」を評価した．平均評点は5点満点でそれぞ れ3.9，4.0，1.9となり，30文字/行は小さ過ぎて字幕には適 当ではないことがわかった．20文字/行と25文字/行は観視 者の好みが分かれた.より見やすいハイビジョン画面用字 幕を実現するためには, NTSCでの字幕呈示法の場合と同様, さまざまな変動パラメータを用いた検討が必要である.

\section{4 字幕呈示パラメータ}

予備実験を基に，文字の大きさと文字数を決めた.

(1) 1 行当たりの文字数

1行当たりの文字数は，NTSC字幕の15.5文字を基準とし て，他に20 (20.5) 文字，25文字の3種類を対象とした。

(2) 文字の大きさ

文字の大きさは, サイドカットしたハイビジョン画面の 重要情報範囲にNTSC字幕形式を多重した標準の大きさを 基準とし，他にハイビジョン画面全体の重要情報範囲で1行 を25文字 (NTSC字幕形式と文字の縦横比が同じ) としたと きの大きさの 2 種類を対象とした.

文字の大きさがNTSC字幕形式を多重した基準の時，1行 を20.5文字とするとハイビジョン画面全体の重要情報範囲 となる。

上記より，実験に使用するパラメータの組合せは以下の 5 種類とした。

（1）NTSC重要情報範囲で1行15.5文字8.5行時のサイズ
A : 1行当たり 15.5 文字
B：1行当たり 20.5 文字

(2) ハイビジョン重要情報範囲で1行25文字 (NTSC字幕 文字と同縦横比) のサイズ

C：1行当たり15.5文字

D：1行当たり20文字

$E ： 1$ 行当たり 25 文字

図1に字幕作成例を示す.

\section{5 字幕付加番組の種類}

番組により登場事物の動作や画面の切替わりが異なり, 受けて側にとって見やすい字幕の呈示方法に影響を与える ことが考えられる.そこで代表的な番組の種類として以下 の4種類を用意した.

(1) ドラマ番組“ドラマ“

(2) ニュース番組“ニュース”

(3) スポーツ番組 “相撲”

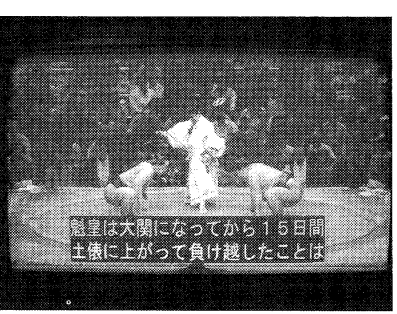

(a) Aの場合

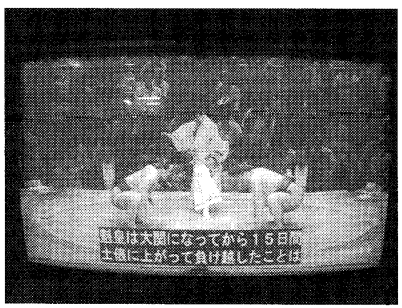

（c）Cの場合

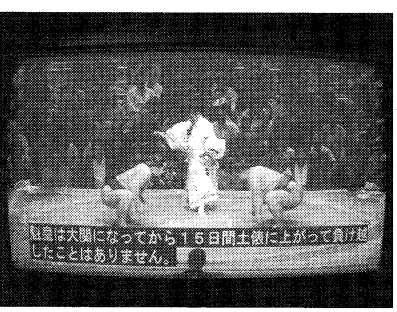

(e)Eの場合

\section{図1 字幕作成例}

Samples of captions produced for the tests.

（4）情報番組 “情報”

各番組は約 1 ～1.5分ずつ部分的に切出し $2.1 て ゙$ 示した 5 種類 の字幕を付加して使用することとした４番組に5種類の字 幕を付加し，計 20 種類の評価素材を用いた。

\section{3. 評価用の字幕映像の作成}

\section{1 字幕作成方法}

ハイビジョン用の字幕制作設備が整備されていないた め, 字幕は一枚一枚パソコンの作画ソフトを用いて作成し, 専用のソフトで電子テロップ用の静止画素材にした。この 際対応するキー信号用の静止画素材も作成した１つの番 組素材当たり約15枚の字幕を作成し，組合せにより計 20 種 類の素材を用いたため, キー信号用素材と合わせ, 全部で 約600枚の静止画素材を作成した。作成した静止画素材は ハイビジョン編集室で番組素材に合成した。

\section{2 評価用字幕の詳細}

変動パラメータ以外の字幕呈示法は以下の通りである.

(1) 字幕呈示時間

字幕や映像の見やすさは文字数だけではなく，表示時間 の影響も考えられるが, 字幕表示時間は下記の日本文字放 送の表示方針に沿って決めた5).

- 8 文字以内 $\cdot 2$ 秒

-16文字以内 $\cdot$. 4 秒

- 24 文字以内 ・ $\cdot 6$ 秒

-30文字以内 ・ 7.5 秒 $* 1$

·最短表示秒数は 2 秒 $* 2$ 
(2) 字幕表示行

一般的な字幕放送を考え, 字幕表示は最大で2行まで, 画面の下から2行を使用した.

(3) 字幕文字 · 背景色

字幕表示は文字の場合半輝度色を含む13色あり，その中 で現在字幕放送で使われているのは白, 黄, シアン, 緑で ある．また背景色は黒と半輝度の黒 (グレー)である．本実 験では文字色を白，背景色を黒とした。

\section{4. 主観評価実験}

\section{1 主観評価法}

主観評価法は5段階品質尺度 (5. 良い，4．やや良い， 3. 普通, 2. やや悪い, 1. 悪い)による単一刺激法を用いた. ダミー映像の呈示に続いて，グレー映像を間に挟みながら 評価映像を呈示し，「映像の見やすさ」，「字幕の見やすさ」, 「全体の評価」の3項目を評価させた.

評定者はテレビ技術者 16 人で, HDTV標準観視条件の下 ${ }^{4)}$, 32インチのCRTを用いて評価を実施した.

\section{2 評価と考察}

「字幕の見やすさ」,「映像の見やすさ」,「全体の評価」に 対する評価結果をそれぞれ図2 (a)～図2 (c) に示す (図中の) $\mathrm{A} \sim \mathrm{E}$ は2.3で示した文字サイズと文字数の組合せを示す). また, 評価デー夕に 3 元配置法 (2母数1変量繰返しなし) の分 散分析を適用し，「全体の評価」に対する分析結果を表1に 示す.

図中の最小有意差は, 分散分析により求めた有意水準 $5 \%$ の值であり，任意の平均值の差が有意なものか否か の判定基準である ${ }^{6)}$.

表1より，有意水準5\%で要因“パラメー夕（文字サイズ\& 文字数)”と“番組”に有意な効果が認められた。“パラメー 夕”と“評定者”の交互作用に有意差が認められたが，“番 組”と“評定者”の交互作用には有意差が認められなかった. 他の2項目についても同様であった。これより，最適な“パ ラメータ（文字サイズ\&文字数）”があることおよび “番組” により「全体の評価」が変わる可能性があることがわかる.

図2 (a)より，「字幕の見やすさ」は，すべての“番組”で 現行方式 (A) が最も良い. 現行の文字サイズでも文字数を 増やす (B) と評点が低くなる傾向がある，文字サイズを小 さくした場合，1行20文字 (D) が最適でこれより文字数が 多くても $(\mathrm{E})$ ，少なくても $(\mathrm{C})$ 評点は下がる.

これより，「字幕の見やすさ」は文字サイズと一行当たり の文字数の両方と密接な関係があり，文字サイズに応じて 最適な文字数が存在することがわかる．一行当たりの文字 数が多くなり，目を動かす範囲が広くなるため，「字幕の 見やすさ」が低下すると考えられる。「字幕の見やすさ」が(,

*1 ドラマや早口のトーク番組などの場合は, 番組の䨌囲気や演出意図に 配慮するため，必ずしもこの基準を守る訳ではない.

*22 2秒で表示する字幕は, 「文章」ではなく, あいさつ・呼びかけ程度の 短いもの.

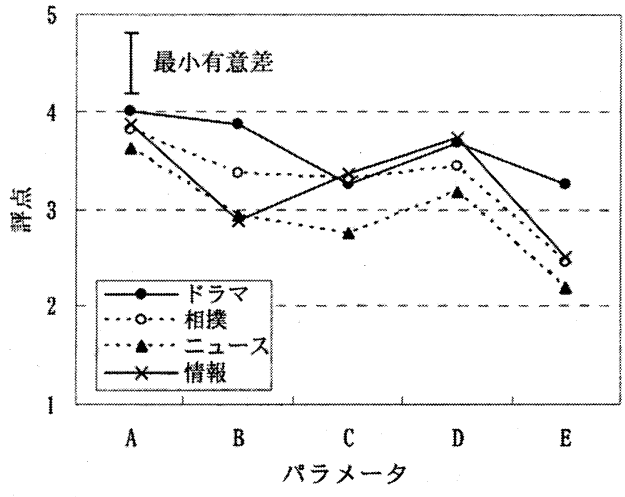

(a)「字幕の見やすさ」

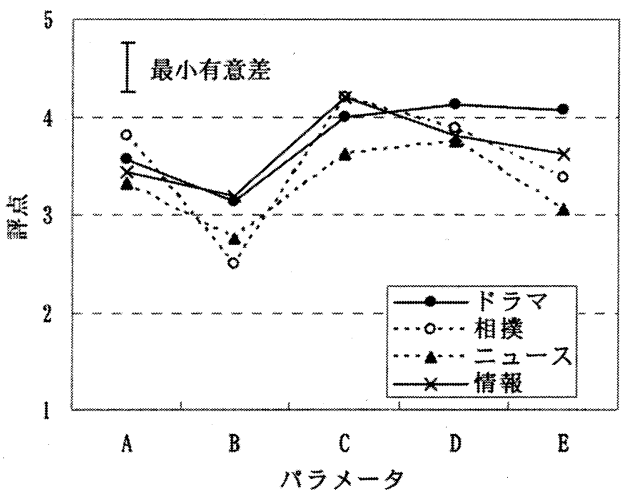

(b)「映像の見やすさ」

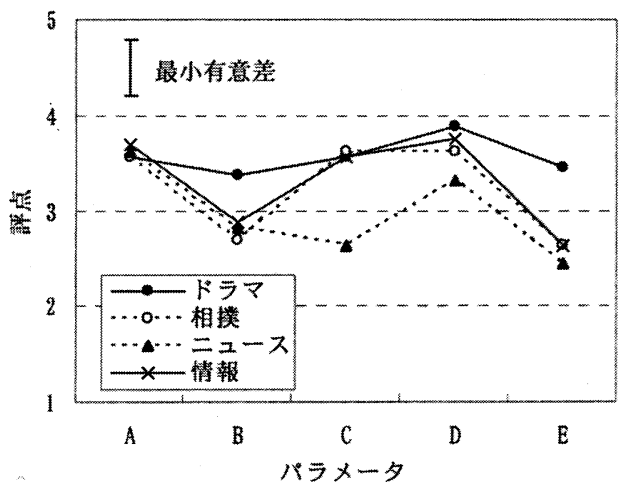

(c)「全体の評価」

図2 主観評価結果

Results obtained by the subjective evaluation tests.

表1 分散分析表（全体の評価）

Analysis of variance table (Total evaluation)

\begin{tabular}{|c|c|c|c|c|}
\hline 要 因 & $\begin{array}{c}\text { 偏差の } \text { 自 } \\
\text { 乘和 }\end{array}$ & 自由度 & 不価分散 & Fo \\
\hline パラメータA & 48.1438 & 4 & 12.0359 & $6.4300 *$ \\
\hline 霜 組 B & 9.7375 & 3 & 3.2458 & $9.8929 *$ \\
\hline 評定者 C & 110.3875 & 15 & 7.3592 & $3.9694 *$ \\
\hline$A \times B$ & 10.7312 & 12 & 0.8943 & 2. 6213* \\
\hline$B \times C$ & 21.5625 & 45 & 0.4792 & 1.1617 \\
\hline$A \times C$ & 56.4563 & 60 & 0.9409 & $3.5613 *$ \\
\hline 残 美 E & 67.4688 & 180 & 0.3748 & \\
\hline
\end{tabular}


D）より（C）で低下する原因は，一行当たりの文字数が少 ないため，(D) と比べて時間方向に字幕を分割呈示してお り, 次の字幕が呈示されるまで待たなければならないこと が影響していると推測される.この推測を裏付ける実験後 の評定者のコメントも複数あった. 今後, 字幕呈示時間に ついても検討する必要がある.

図2（b）より，「映像の見やすさ」は，現行方式より文字 サイズを小さくした方が良くなる傾向が強いが, 文字数を 増やす (E) と評点が低くなる傾向がある. 現行方式で文字 数を増やした $(\mathrm{B})$ の場合が最も評点が低い.

「映像の見やすさ」の良し悪しは, 字幕を呈示することに より隠される映像領域の大きさとほぼ一致している.

図2 (c)より，「全体の評価」は，番組“ニュース”を除い て現行方式 (A)より1行20文字 (D) の方が評点が高い.こ れより, 現行より小さな文字サイズで文字数を増やした字 幕の方がハイビジョン番組に適している可能性があること がわかる.“ニュース”に関しては「字幕の見やすさ」と「全 体の評価」の傾向が似ており，「全体の評価」に「映像の見 やすさ」が寄与していないことがわかる，この傾向は，“文 字が大きい方が良い”とのコメントが多かったことからも 裏付けられる。これは，“ニュース”で使用した映像の被写 体がアナウンサのみであり，映像内容の持つ意味が低かっ たことが原因していると考えられる。

また，番組“ドラマ”は，文字サイズ\&文字数の影響は小 さく，番組“相撲”と“情報”はほぼ同一の結果を示した. 番組“ドラマ”は，二人の男女が会話をしているシーンであ り, 字幕が一行を埋め尽くさない場合がほとんどであった ことが影響していると推測される.

以上より，「全体の評価」は絵柄 (シーン) に大きく依存す ることがわかる，番組 “相撲”と“情報”について，重回帰 分析を行う.

【重回帰分析結果 (括弧内は重相関係数)】

「全体の評価 $\rfloor=\alpha \cdot\lceil$ 字幕 $\rfloor+\beta$ ·「映像 $\rfloor+\gamma$

“相撲” : $a=0.6612, \quad \beta=0.5267, \quad \gamma=-0.9101(0.9845)$

“情報” : $a=0.8124, \quad \beta=0.3069, \quad \gamma=-0.4810(0.9977)$

有意水準 $5 \%$ で回帰変動が有意差を示したことより, 両 方の番組に対する「全体の評価」は「字幕の見やすさ」と「映 像の見やすさ」を両方のバランスを考慮して評価している ことがわかる.

上述したように，“ドラマ”は文字サイズ\&文字数の影響 は小さく, 重回帰分析を実施しても有意な回帰変動を示さ
なかった。“ニュース”も同様に回帰直線に乗らなかった (原因は上述通り).

\section{5.むすび}

字幕文字の大きさと 1 行当たりの文字数をパラメータと して, 主観評価実験によりハイビジョン番組に最適な字幕 呈示法の検討を行った。まず，評価デー夕に分散分析法を 適用し，最適な文字サイズ\&文字数があることおよび番組 (絵柄）により「全体の評価」が変わる可能性があることを 示した. 次に，「字幕の見やすさ」については，文字数に応 じて最適な文字数が存在すること，「映像の見やすさ」は， 字幕で隠れる映像領域の大きさとほぼ一致することを示し た.さらに，「映像の見やすさ」，「字幕の見やすさ」，「全 体の評価」の3項目の評点を分析し，現行より小さな文字サ イズで文字数を増やした字幕の方がハイビジョン番組に適 している可能性があることがわかった.

今後, 絵柄の特徵と文字サイズ\&文字数の関係を明らか にして行く予定である．また，「字幕」と「映像」の見やす さを考慮して「全体の評価」を行った場合とそうでない場合 があり, 番組数を増やして検討を行う予定である.

\section{〔文 献〕}

1）沢村英治, 棚橋大介, 江原睡将, 白井克彦：“実験用字幕つきテレビ ニュースの制作と字幕表示法に関する予備評価”，映情学誌，53，4， pp.634-638 (1999)

2) 阴馬隆雄, 沢村英治, 三橋哲雄, 江原睴将, 白井克彦: “聴覚障害者 向けニュース字幕呈示方法に関する主観評価”，映情学誌，54，9， pp.1288-1297 (2000)

3) "Recommendation $500-10$; Methodology for the subjective assessment of the quality of television pictures", ITU-R Recommendations (2000)

4) "Recommendation 710-4 ; Subjective assessment methods for image quality in high-definition television", ITU-R Recommendations, RBT (1998)

5) http://www.telemo.co.jp/jimaku/jimaku-main6.html

6）石川馨, 藤森利美, 久米均：“化学者挹よび化学技術者のための実験 計画法 (上)”, 東京化学同人 (1967)

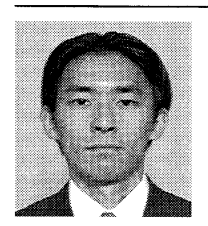

工藤 妄犮彦 2002年, 慶應義塾大学理工学研究科修士 課程修了. 同年, NHKに入局. 放送技術局に勤務。自律 型ロボットの学習効率に関する研究, 字幕呈示法に関す る研究に従事.

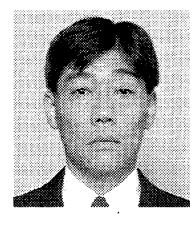

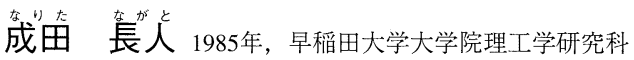
修士課程修了．同年，NHKに入局．大阪放送局を経て， 1988年より，放送技術研究所に勤務。画質の主観評価法, 評価デー夕の統計処理法, 映像処理, ネットワークの放 送応用に関する研究に従事. 現在, 放送技術局副部長. 工学博士. 正会員. 